\title{
ANALISIS PENGGUNAAN FOAM POLYURETHANE PADA KAPAL IKAN 5 GT SEBAGAI DAYA APUNG CADANGAN DI PT. JELAJAH SAMUDERA INTERNASIONAL KABUPATEN JEPARA
}

\author{
Analysis of Foam Polyurethane Usage for 5 GT Fiber Fishing Boat as Buoyancy Alternative \\ at PT. Jelajah Samudera Internasional, Jepara Regency \\ Herry Boesono, Meita Saraswati, dan Indradi Setiyanto \\ Program studi Pemanfaatan Sumberdaya Perikanan \\ Fakultas Perikanan dan Ilmu Kelautan, Universitas Diponegoro \\ J1. Prof. Soedharto, SH. Tembalang, Semarang \\ Email: herryboesono@gmail.com, dan meitasaraswati00@gmail.com
}

Diserahkan tangga 14 September 2017, Diterima tanggal 9 Januari 2018

\begin{abstract}
ABSTRAK
Kapal fiber bila terjadi kebocoran di laut maka kapal akan tenggelam, hal tersebut dikarenakan massa jenis fiber lebih besar daripada massa jenis air, oleh karena itu perlu dianalisis dan dihitung seberapa banyak foam polyurethane tersebut yang diperlukan untuk mengapungkan kapal sesuai dengan berat kapal yakni 5 GT. Penelitian ini dilakukan pada bulan Oktober-Desember 2017, bertempat di PT. Jelajah Samudera Internasional dan Laboratorium Fishing Boat Departemen Perikanan Tangkap Universitas Diponegoro. Tujuan penelitian ini yaitu untuk menganalisis kemampuan daya apung cadangan berbahan polyurethane dan Menghitung kebutuhan jumlah dan harga foam polyurethane yang di perlukan untuk mengapungkan kapal ikan fiber 5 GT yang dibuat di PT. Jelajah Samudra Internasional Kab. Jepara. Metode yang digunakan adalah metode deskriptif dengan dua tahap pelaksanaan, yakni penelitian di galangan dan penelitian skala laboratorium dalam spesimen kecil. Hasil yang diperoleh dari penelitian yaitu bahwa foam polyurethane dengan berat 15 gr dapat menahan beban fiber sebesar $1 \mathrm{~kg}$. Hasil uji apung didapatkan untuk mengapungkan kapal ikan fiber $5 \mathrm{GT}$ dibutuhkan $45 \mathrm{~kg}$ foam polyurethane. Kebutuhan harga foam polyurethane yang dibutuhkan untuk satu kapal yakni sebesar $\operatorname{Rp} 2.475 .000$.
\end{abstract}

Kata kunci: Kapal Ikan Fiber 5 GT; Keselamatan Kapal; Foam Polyurethane

\section{ABSTRACT}

Fiber ship are very difficult to overcome when there is a leakage in the sea and its possible for the ship to sink. Therefore, it needs to be analyzed and calculated how much polyurethane foam is needed, how many liters if its melted and how much the volume when it becomes a polyurethane foam solid. This research was conducted in October-December 2017, held at PT. Jelajah Samudera Internasional and Laboratory Fishing Boat Department of Capture Fisheries, Diponegoro University. The purpose of this study is to analyze the capability of alternative buoyancy polyurethane then calculate and analyze the quantity that needed and foam polyurethane price to float the 5 GT fiber fishing ship that made in PT. Jelajah Samudera Internasiona, Jepara Regency. The method used is descriptive with two steps of implementation, i.e. research in the shipyard and laboratory scale in small specimens. The results from the research obtain that the polyurethane foam with $15 \mathrm{gr}$ weight can hold $1 \mathrm{~kg}$ fiber load. The float test results revealed that to float fiber fishing ships with a size of $5 \mathrm{GT}$, needs $45 \mathrm{~kg}$ of polyurethane foam. The price needed to float the ship is $\mathrm{Rp} 2.475 .000$.

Keywords: 5 GT Fiber Fishing Ship; Safety of ship; Foam Polyurethane

\section{PENDAHULUAN}

Keragaman jenis kapal perikanan di Indonesia diantaranya yang berbahan kayu, baja dan fiberglass, dari berbagai jenis bahan kapal tersebut, kapal kayu yang paling banyak digunakan oleh para nelayan. Semakin sulitnya bahan kayu yang berkualitas untuk kapal maka kapal berbahan fiber sebagai alternatif, hal tersebut memungkinkan untuk dikembangkan karena harga lebih murah dibandingkan kapal kayu, tetapi ada beberapa hal yang perlu dikaji atau di teliti berkaitan dengan keselamatan di laut karena kapal fiber sangat susah ditanggulangi bila terjadi kebocoran di laut dan kapal akan tenggelam. Hal ini diperkuat oleh Setiyanto dan Hartoko (2006), polyurethane mulai di gunakan sebagai bahan apung pada kapal-kapal fiber (semua rongga kapal dicor menggunakan polyurethane) yang berfungsi sebagai daya apung cadangan pada kapal, sehingga kapal tidak mudah tenggelam bila terjadi kebocoran di laut. Menanggulangi hal tersebut maka perlu penelitian tentang bahan atau material sebagai daya apung cadangan, sehingga apabila terjadi kebocoran ditengah laut kapal akan tetap terapung (tidak tenggelam). Keunggulan polyurethane untuk kapal perikanan yakni dapat digunakan sebagai bahan isolator untuk palka ikan 
dan dapat digunakan untuk memperkuat konstruksi pada badan kapal. Penelitian tersebut peneliti menggunakan foam dari polyurethane sebagai bahan apung cadangan yang sudah terpasang pada kapal fiber dan digunakan sebagai bahan isolator palka. Foam dari polyurethane tersebut terpasang sepanjang disekitar dinding palka, setelah diketahui kebutuhan foam polyurethane untuk satu kapal maka dapat diketahui kebutuhan harga foam polyurethane untuk satu kapal sesuai dengan harga polyurethane per $\mathrm{kg}$ yang digunakan galangan kapal.

Penelitian ini dilakukan di PT. Jelajah Internasional Kabupaten Jepara dengan melakukan kajian tentang analisis penggunaan foam polyurethane sebagai daya apung cadangan pada kapal ikan berbahan fiberglass, dengan ukuran kapal 5 GT dan berat sebesar 3 ton. Ukuran kapal disesuaikan dengan produksi yang ada pada galangan kapal. Kapal berbahan fiber tersebut supaya dapat tetap mengapung pada saat kapal terjadi kebocoran dilaut, sehingga Foam Polyurethane tersebut dapat berfungsi sebagai daya apung cadangan untuk keselamatan dilaut. Hal ini diperkuat oleh Amiruddin et al. (2014), yang menyatakan bahwa polyurethane mulai di gunakan sebagai bahan apung kapal fiberglass, berfungsi sebagai daya apung cadangan sehingga kapal tidak mudah tenggelam bila terjadi kebocoran.

Pentingnya kesempurnaan suatu desain kapal ikan dalam menjamin keberhasilan operasional dan keselamatan kerja di laut, maka diperlukan suatu kajian yang sistematik dan kompleks terhadap kapal berbahan fiberglass. Kapal fiberglass bila terjadi kebocoran dilaut susah ditanggulangi dan untuk menutup kebocoran tersebut kapal harus di bawa ke darat terlebih dahulu, maka dari itu supaya kapal tidak tenggelam kapal tersebut perlu dipasang foam polyurethane sesuai dengan beratnya. Bagian lambung kapal diberi lapisan foam polyurethane yang berfungsi sebagai bahan isolator palka dan untuk menahan supaya kapal tersebut tetap terapung dan dengan foam polyurethane tersebut kapal masih dapat mengapung di perairan. Hal tersebut perlu dianalisis dan dihitung seberapa banyak foam polyurethane tersebut yang diperlukan, seberapa liter saat cair dan menjadi berapa volume saat menjadi padatan foam polyurethane. Hal ini diperkuat oleh Amiruddin et al. (2014), Alasan ini yang membuat beberapa komunitas pengrajin kapal ikan tradisional beralih ke polyurethane sebagai material insulasi dalam palka, di mana sebelumnya banyak digunakan alternatif material insulasi yang lain diantaranya sterofoam. Keuntungan polyurethane terhadap polystyrene adalah sifat konduktivitas termal yang lebih rendah, mudah dalam pemasangan.

Tujuan dari penelitian ini adalah menganalisis kemampuan daya apung cadangan berbahan polyurethane dan menganalisis kebutuhan jumlah dan harga foam polyurethane yang di perlukan untuk mengapungkan kapal ikan fiber 5 GT.

\section{METODE PENELITIAN}

Metode yang digunakan dalam penelitian ini adalah metode Deskriptif. Penelitian ini terdiri atas dua bagian, yakni penelitian pengamatan langsung di galangan dan penelitian skala laboratorium. Penelitian pengamatan langsung dimaksudkan untuk melihat proses pembuatan atau pengecoran polyurethane, proses pembuatan kapal ikan berbahan fiberglass, mengukur ukuran utama pada kapal dan kemudian mengambil sampel foam polyurethane dengan ukuran yang sudah dipakai di galangan dan fiber yang nantinya digunakan untuk uji apung skala laboratorium. Penelitian skala laboratorium dimaksudkan untuk menguji kemampuan daya apung cadangan dengan bahan foam polyurethane dalam spesimen kecil. Penelitian skala laboratorium dilakukan menggunakan tiga sampel dari bahan foam polyurethane yang nantinya akan dilakukan untuk uji apung. Uji apung dilakukan selama $3 x$ pengulangan dalam selang waktu 24 jam

Analisis data dilakukan berdasarkan hasil pengukuran berat foam polyurethane sampel dan volume sampel melalui pengukuran secara langsung, sehingga didapatkan densitas pada sampel foam polyurethane tersebut. Hasil analisa perhitungan densitas foam polyurethane dari sampel tersebut, maka dilakukan uji kemampuan apung dengan dilakukannya 3x pengulangan dan kemudian diambil rata-ratanya. Langkah selanjutnya menganalisa kebutuhan jumlah dan harga foam polyurethane yang diperlukan untuk mengapungkan kapal ikan fiber berbahan polyurethane dengan besaran 5 GT yang digunakan sebagai daya apung cadangan pada kapal.

Densitas adalah jumlah zat yang terkandung dalam suatu unit volume. Densitas merupakan suatu besaran kerapatan massa benda yang dinyatakan dalam benda per satuan volume benda tersebut. Besaran massa jenis dapat membantu menerangkan mengapa benda yang berukuran sama memiliki berat yang berbeda (Torryselly, 2008).

$$
\rho=\frac{m}{V}
$$

Dimana:

$\rho=$ Massa jenis / Densitas $\left(\mathrm{kg} / \mathrm{m}^{3}\right)$

$\mathrm{m}=$ massa Foam Polyuerthane $(\mathrm{kg})$

$\mathrm{V}=$ Volume Polyuretane $\left(\mathrm{m}^{3}\right)$

Menurut ilyas (1998), berikut merupakan sifat-sifat penting beberapa material insulasi yang biasa digunakan adalah sebagai berikut:

Tabel 1. Densitas material insulasi

\begin{tabular}{ccc}
\hline No. & Material & Densitas $\left(\mathrm{kg} / \mathrm{m}^{3}\right)$ \\
\hline 1. & Lempeng gabus & $100-150$ \\
2. & Foam-glass & 145 \\
3. & Polystyrene & $15-30$ \\
4. & Polyurethane & 40 \\
\hline
\end{tabular}

Sumber: Ilyas Sofyan, (1998).

Tabel sifat-sifat material insulasi Menurut Dellino (1997), dapat di indikatorkan sebagai berikut:

Tabel 2. Densits Polyurethane

\begin{tabular}{lcc}
\hline No. & Densitas $\left(\mathrm{kg} / \mathrm{m}^{3}\right)$ & Kriteria \\
\hline 1. & $>30$ & Baik \\
2. & $\leq 30$ & Tidak baik \\
\hline
\end{tabular}

Sumber: Dellino, (1997).

Densitas/ kerapatan yang dihasilkan akan mempengaruhi hasil uji apung pada foam polyurethane. Jika densitas/ kerapatan pada foam polyurethane $\leq 30 \mathrm{~kg} / \mathrm{m}^{3}$ maka foam polyurethane dikategorikan tidak baik. Jika densitas/ kerapatan pada foam polyurethane $>30 \mathrm{~kg} / \mathrm{m}^{3}$ dikategorikan baik, akan tetapi jika nilai nya terlalu tinggi akan mengakibatkan teksturnya menjadi semakin keras. Densitas/ kerapatan yang baik yaitu foam polyurethane $=40 \mathrm{~kg} / \mathrm{m}^{3}$, karena tekstur yang dihasilkan tidak terlalu lembek dan tidak

\footnotetext{
(C) Copyright by Saintek Perikanan (Indonesian Journal of Fisheries Science and Technology), ISSN : 1858-4748
} 
terlalu keras. Hal tersebut tentunya akan berpengaruh terhadap kemampuan daya apung pada foam polyurethane dalam menahan beban yang diberikan, semakin berat foam polyurethane, maka densitas/ kerapatan yang dihasilkan semakin besar dan mengakibatkan rendahnya kemampuan apung dalam menahan beban pada foam polyurethane tersebut. Menurut Setiyanto dan Hartoko (2006), semakin rapat massanya pada foam polyurethane akan mengakibatkan rendahnya kemampuan apung pada foam polyurethane tersebut.

Menurut Setiyanto dan Hartoko

(2006), kebutuhan Jumlah Foam Polyurethane untuk mengapungkan kapal dapat dihitung sebagai berikut:

$$
\text { Hasil uji apung } \times \frac{\text { Berat kapal }}{\text { Berat spesimen }}
$$

Analisis Kebutuhan harga Foam Polyurethane untuk satu kapal dapat dihitung sebagai berikut:

Total biaya $=$ Kebutuhan jumlah polyurethane $\times$

Harga polyurethane per $\mathrm{kg}$

\section{HASIL DAN PEMBAHASAN}

\section{Ukuran Utama Kapal}

Galangan PT. Jelajah Samudera Internasional terletak di Desa Bandengan, Kabupaten Jepara. Galangan tersebut memproduksi kapal ikan berbahan dasar fiberglass. Kapal yang di produksi berukuran 5 GT. Menurut Farhum (2010), Bentuk badan kapal bergantung pada ukuran utama, perbandingan ukuran utama dan koefisien bentuk kapal. Ukuran utama kapal terdiri dari panjang kapal (L), lebar kapal (B), tinggi atau dalam kapal (D) dan draft atau sarat air kapal (d). Kesesuaian rasio dimensi sangat menentukan suatu kapal ikan, karena rasio tersebut akan mempengaruhi resistensi kapal (nilai L/B), kekuatan memanjang kapal (nilai B/D). Berikut merupakan data pengukuran kapal yang diperoleh adalah sebagai berikut: Tabel 3. Pengukuran Kapal

\begin{tabular}{clc}
\hline No & \multicolumn{1}{c}{ Keterangan } & Ukuran (m) \\
\hline 1. & Panjang seluruh kapal (Loa) & $11 \mathrm{~m}$ \\
2. & Lenght Water Line (LWL) & $9,15 \mathrm{~m}$ \\
3. & Lenght Deck Line (LDL) & $10,68 \mathrm{~m}$ \\
4. & Lenght Between & $9,40 \mathrm{~m}$ \\
& Perpendicular (LPP) & $2,72 \mathrm{~m}$ \\
5. & Lebar Maksimum (Bmax) & \\
6. & Lebar Kapal (B) & $2,45 \mathrm{~m}$ \\
7. & Tinggi Geladak (H) & $1,20 \mathrm{~m}$ \\
8. & Sarat Benam Air (T) & $1 \mathrm{~m}$ \\
9. & Gross Tonage (GT) & $5 \mathrm{GT}$ \\
10. & Mesin Penggerak & $42 \mathrm{HP}$ \\
& marrine Diesel & $3-5 \mathrm{ABK}$ \\
11. & Awak Kapal (ABK) & $3 \mathrm{Ton}$ \\
12. & Berat Kapal & \\
& Palka & $69 \mathrm{~cm}$ \\
1. & Panjang Palka (P) & $69 \mathrm{~cm}$ \\
2. & Lebar Palka (L) & $95 \mathrm{~cm}$ \\
3. & Tinggi Palka (D) & \\
& Bangunan & $1,50 \mathrm{~m}$ \\
1. & Tinggi Bangunan & $1,75 \mathrm{~m}$ \\
2. & Lebar Bangunan & $4,46 \mathrm{~m}$ \\
3. & Panjang Bangunan & \\
\hline
\end{tabular}

Sumber: Penelitian, 2017.

Berdasarkan tabel 3, hasil pengukuran diperoleh ukuran-ukuran utama pada kapal ikan fiber dengan besaran 5 GT. Diketahui bahwa untuk pengukuran kapal dilakukan dari luar lambung kapal, karena bentuk lambung bagian haluan memiliki bentuk lambung yang paling banyak lengkungan. Berat kapal tergantung pada beberapa kondisi yang diantaranya adalah LWL, lebar kapal dan kondisi berat kapasitas muatan. Hal ini diperkuat oleh Nurhasanah (2016), yang menyatakan bahwa berat kapal diperoleh dari hasil perkalian antara luasan kapal dengan berat tiap meter persegi $\left(\mathrm{m}^{2}\right)$.

Bentuk dan ukuran suatu kapal akan berpengaruh terhadap kekuatan kapal tersebut diatas laut. Ukuran panjang kapal (L), mempunyai pengaruh pada kecepatan kapal. Perbandingan tinggi dan syarat kapal akan berpengaruh terhadap daya apung cadangan. Bentuk panjang dan tinggi kapal L/H mempunyai pengaruh terhadap kekuatan memanjang pada kapal. Hal ini diperkuat oleh Suryana et al. (2013), bentuk dan ukuran dari suatu kapal akan berpengaruh terhadap kekuatan kapal tersebut diatas laut seperti dalam menahan suatu ombak. Selain itu ukuran kapal berpengaruh terhadap pergerakan kapal tersebut dilaut. GT kapal akan berpengaruh terhadap hasil tangkapan ikan. Semakin besar GT kapal semakin besar hasil tangkapan.

\section{Proses Pengecoran Polyurethane di Galangan}

Galangan kapal PT. Jelajah Samudera Internasional menggunakan Polyurethane pada bagian lambung kapal dan pada palka kapal yang berfungsi sebagai daya apung cadangan pada kapal ikan berbahan Fiberglass. Jika pada palka kapal dilapisi dengan foam poyurethane yang berguna sebagai lapisan insulasi pada kapal, supaya suhu pada palka tetap stabil. Hal ini diperkuat oleh Zemansky dan Ditman (1986), Polyurethane merupakan jenis material insulasi berbentuk busa yang didalamnya mengandung gas. Gas pada umumnya merupakan penghantar kalor yang paling buruk. Oleh sebab itu, pemilihan jenis material ini sebagai insulasi merupakan alternatif yang cukup baik. Berdasarkan Gambar 5 pada metode, merupakan tahapan-tahapan dalam proses pengecoran atau pembuatan Foam Polyurethane, berikut merupakan penjelasan dari bagan alir pada gambar 5 adalah sebagai berikut:

1. Polyurethane A dengan merk Isocyanate dan Polyurethane B dengan merk Polyol yang nantinya akan dicampur menjadi satu dengan perbandingan campuran sebesar 1:2. Ukuran perbandingan campuran polyurethane tersebut sesuai dengan penggunaan turuntemurun yang digunakan pada galangan kapal tersebut, dimana Polyurethane B dominan lebih banyak daripada Polyurethane A, karena jika campuran Polyurethane A terlalu banyak nantinya foam akan menjadi lembek. Begitupula sebaliknya, jika Polyurethane B terlalu banyak akan mengakibatkan foam menjadi terlalu keras.

2. Setelah pencampuran antara polyurethane A dan polyurethane $\mathrm{B}$, langkah selanjutnya adalah pengecoran polyurethane kedalam cetakan. Pemakaian pada galangan tersebut, cetakan di lapisi dengan oli terlebih dahulu, hal tersebut dikarenakan supaya mempermudah dalam pelepasan foam polyurethane pada cetakan.

3. Tahapan selanjutnya yaitu jika polyurethane sudah dicor kedalam cetakan, diamkan selama kurang lebih 20 menit. Foam polyurethane akan mengembang keatas dan ke samping mengikuti ruang kosong pada bentuk cetakan.

4. Tahapan terakhir yaitu pelepasan pada foam Polyurethane dari cetakan, foam polyurethane dilepas dari cetakan menggunakan tenaga manusia secara

(C) Copyright by Saintek Perikanan (Indonesian Journal of Fisheries Science and Technology), ISSN : 1858-4748 
manual. Setelah jadi, bentuknya menjadi seperti foam dan beratnya ringan. Setelah tahapan selesai, foam polyurethane dipotong memanjang berbentuk persegi panjang yang ukurannya sudah ditentukan, yang nantinya akan dipasang di bagian lambung kapal fiber.

Menurut Amiruddin et al. (2014), keuntungan dalam penggunakan polyurethane terhadap polystyrene adalah sifat konduktivitas termal yang lebih rendah serta mudah dalam pemasangannya.

\section{Proses Pembuatan Kapal Ikan Fiber 5 GT}

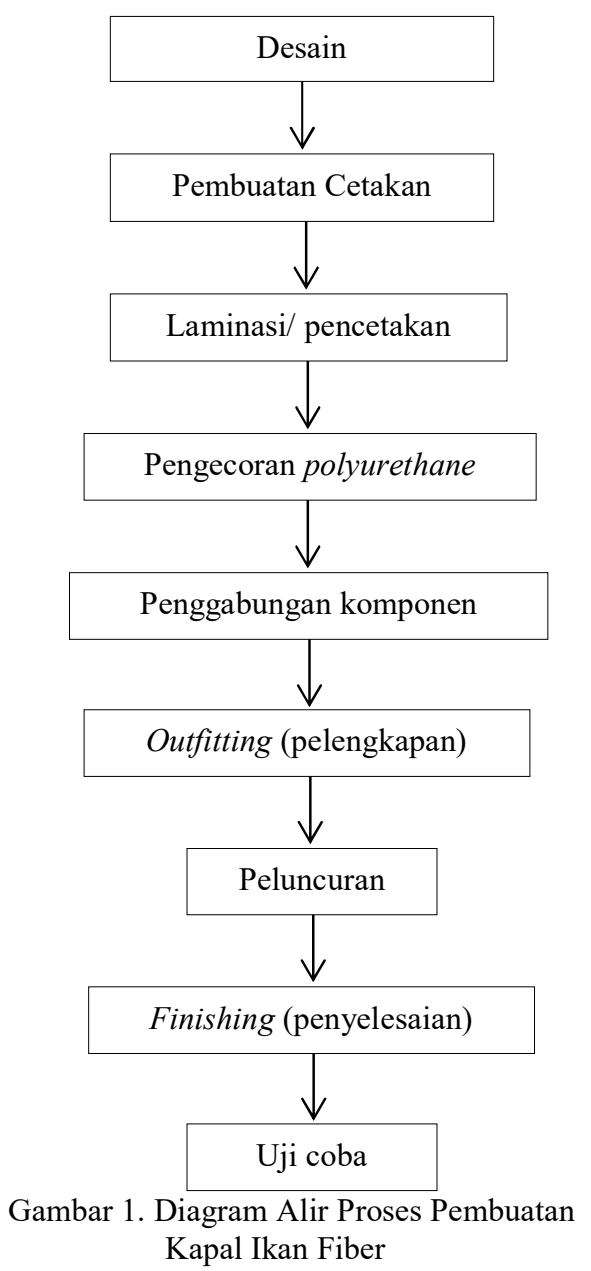

\section{Uji Apung Skala Laboratorium}

Pengujian laboratorium ini bertujuan untuk menguji dan menganalisis kemampuan daya apung cadangan dengan bahan foam polyurethane. Langkah selanjutnya dilakukan dengan perhitungan foam polyurethane yang diperlukan untuk mengapungkan kapal sesuai dengan berat kapal. Pengujian ini dilakukan dengan skala laboratorium, menggunakan foam polyurethane sebagai uji apungnya dan fiber sebagai pemberat dari sampel. Penggunaan pemberat fiber dikarenakan kapal tersebut yang terbuat dari bahan fiber. Sampel tersebut didapatkan dari galangan. Ukuran sampel foam polyurethane yang nantinya akan digunakan sebagai bahan uji apung, disesuaikan dengan ukuran foam yang dipasang pada lambung kapal. Ukuran sampelnya yaitu $10 \mathrm{~cm}$ x10 cm x5 cm. Ukuran sampel foam polyurethane tersebut disesuaikan dengan penggunaan pada galangan kapal yang sudah terpasang pada lambung kapal. Uji apung dilakukan dengan 3x pengulangan, karena supaya data yang didapatkan valid dan kemudian diambil rata-ratanya. Tahapan dalam uji apung terdapat pada bab metode yang tersaji pada tabel berikut:

Tabel 4. Pengukuran Sampel

\begin{tabular}{|c|c|c|c|}
\hline No. & Bahan & $\begin{array}{l}\text { Berat } \\
\text { (gr) }\end{array}$ & $\begin{array}{c}\text { Volume } \\
\text { (P X L X T) }\end{array}$ \\
\hline \multirow[t]{4}{*}{1.} & $\begin{array}{l}\text { Foam Polyurethane } \\
\text { (PU) }\end{array}$ & & \\
\hline & - Sampel I & 25 & $\begin{array}{l}10 \mathrm{~cm} \times 10 \mathrm{~cm} \mathrm{x} \\
5 \mathrm{~cm}=500 \mathrm{~cm}^{3}\end{array}$ \\
\hline & - Sampel II & 27 & $\begin{array}{l}10 \mathrm{~cm} \times 10 \mathrm{~cm} \mathrm{x}^{2} \\
5 \mathrm{~cm}=500 \mathrm{~cm}^{3}\end{array}$ \\
\hline & - Sampel III & 28 & $\begin{array}{l}10 \mathrm{~cm} \times 10 \mathrm{~cm} \mathrm{x}^{2} \\
5 \mathrm{~cm}=500 \mathrm{~cm}^{3}\end{array}$ \\
\hline 2. & Jaring Sampel & 2 & \\
\hline 3. & $\begin{array}{l}\text { FRP } \\
\text { (Fibre Reinforced } \\
\text { Plastic) }\end{array}$ & 1000 & - \\
\hline
\end{tabular}

Sumber: Penelitian, 2017.

Tabel pengukuran berat sampel diatas didapatkan dengan melakukan pengukuran menggunakan timbangan digital. Ukuran sampel foam polyurethane pada sampel I sampai dengan sampel III sama. Setelah dilakukan penimbangan pada sampel foam polyurethane, ternyata pada tiap-tiap sampel berat yang dihasilkan tidak sama. Pemilihan ukuran sampel foam polyurethane tersebut disesuaikan dengan ukuran yang sudah terpasang pada lambung kapal di galangan. Tahap-tahap dalam melakukan uji apung yang meliputi, langkah awal yaitu mengambil sampel foam polyurethane dari galangan. Selanjutnya dihitung volume dan berat foam polyurethane tersebut, kemudian didapatkan hasil volume foam polyurethane $10 \mathrm{~cm} \times 10 \mathrm{~cm} \times 5 \mathrm{~cm}$. Kemudian ambil sampel fiber yang sudah dipotong persegi, dengan berat $1 \mathrm{~kg}$ yang nantinya akan menjadi pemberat untuk uji apung foam polyurethane. Penggunaan pemberat fiber dikarenakan kapal terbuat dari bahan fiber. Hal ini diperkuat oleh Setiyanto dan Hartoko (2006), ukuran pembebanan dalam uji apung dilakukan dengan berat $1 \mathrm{~kg}$, dikarenakan untuk mempermudah dalam mencari satuannya. Langkah kedua, sampel foam polyurethane yang sudah diberi beban fiber di letakkan ke dalam ember yang sudah terisi air laut sebanyak 120 liter. Peletakkan sampel tidak boleh miring, karena akan kesulitan dalam melakukan pengukuran sampel foam polyurethane. Hal ini diperkuat oleh Setiyanto dan Hartoko (2006), yang menyatakan bahwa besarnya volume pada bagian sampel yang terendam, menunjukkan besarnya dari gaya berat yang bekerja pada bahan uji. Langkah terakhir adalah lakukan pengulangan pengujian sampel foam polyurethane sebanyak tiga kali, karena supaya data yang didapatkan valid.

Hasil uji apung pada penelitian dilakukan selama 32 jam dengan pengamatan setiap 8 jam sekali. Hasil uji apung pada sampel I sampai dengan sampel III berbeda-beda. Hasil uji apung pada semua sampel, pada jam ke- 0 sampai dengan jam ke- 32 mengalami penurunan nilai daya apungnya. Pada semua sampel baik sampel I sampai dengan sampel III titik konstan terjadi pada jam ke-24 dan jam ke-32, hasil nilai daya apung yang dihasilkan sudah konstan. Sampel paling baik terdapat pada sampel I, dikarenakan pada sampel I kemampuan

C Copyright by Saintek Perikanan (Indonesian Journal of Fisheries Science and Technology), ISSN : 1858-4748 
daya apungnya lebih tinggi diantara sampel I dan II. Kemudian sampel dengan nilai kemampuan daya apung paling rendah terdapat pada sampel III. Menurut Dellino (1997), Busa Polyurethane memiliki susunan sel yang tertutup berupa gelembung dalam material, sehingga memiliki dinding tidak terputus.

Perubahan hasil uji apung foam polyurethane pada dikarenakan pada saat pengambilan sampel terjadi perlakuan pemotongan, oleh karena itu susunan sel yang tertutup menjadi rusak dan pada saat dilakukannya uji apung, air dapat masuk pada sampel foam polyurethane tersebut. Setiap sampelnya setelah dilakukannya uji apung berat pada sampel foam polyurethane menjadi bertambah. Hal tersebut dikarenakan adanya volume air yang masuk pada sampel. Pada saat sampel I sampai dengan sampel III memiliki ukuran sampel yang sama yakni 10x10x5 cm, akan tetapi setelah dilakukannya penimbangan dihasilkan berat yang berbeda-beda setiap sampelnya. Hal tersebut menjadi salah satu langkah selanjutnya untuk dilakukan analisa, dengan ukuran sampel yang sama tetapi memiliki berat yang berbeda-beda. Menurut Setiyanto dan Hartoko (2006), diperoleh fakta bahwa bahan Polyurethane memiliki kemampuan apung lebih besar dibandingkan dari bahan Styrofoam. Hal tersebut ditunjukkan dengan kemampuan menahan beban berat dari beban yang bekerja padanya. Besar dari gaya berat yang bekerja pada bahan.

\section{Analisis Kemampuan Daya Apung Foam Polyurethane}

Analisis kemampuan daya apung dengan bahan Polyurethane digunakan untuk menganalisa seberapa besar kemampuan Foam Polyurethane saat menahan beban fiber. Pengujian dilakukan menggunakan pembebanan yang konstan, dengan demikian untuk menganalisa kemampuan daya apung dari Foam Polyurethane dengan cara melihat bagian yang tenggelam di dalam air. Berdasarkan data tenggelam dari bahan uji, dapat ditetapkan kemampuan dalam menahan beban yang sudah ditentukan. Berdasarkan pengukuran yang telah dilakukan didapatkan hasil uji apung foam polyurethane yang tersaji pada gambar berikut:

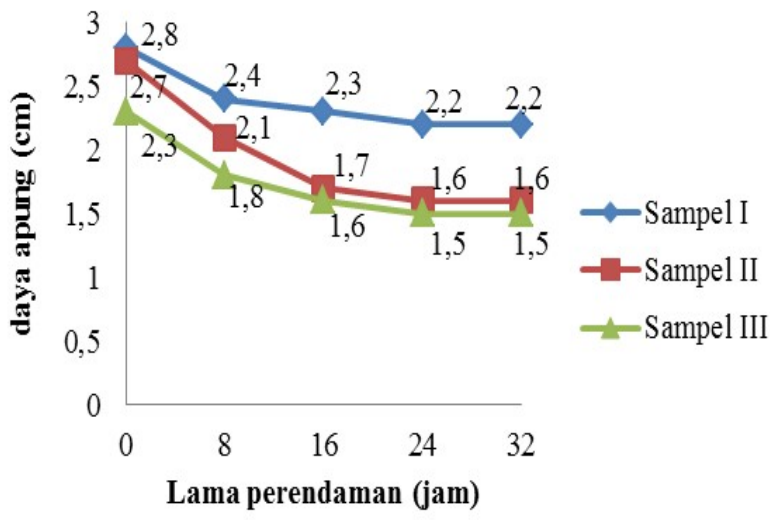

Gambar 2. Grafik Hasil Uji Apung Foam Polyurethane

Berdasarkan gambar 2 diatas, Foam Polyurethane bagian yang terapung dalam air pada saat uji apung sebelum perendaman selama 32 jam dapat diketahui bahwa selama pengulangan 1 sampai dengan 3 , hasil data yang didapatkan mengalami penurunan. Hal ini dikarenakan bahwa densitas/ kerapatan pada tiap-tiap sampel berbeda-beda. Sampel II dan III memiliki kemampuan apung lebih rendah dibandingkan sampel I dikarenakan pada sampel II dan III memiliki ukuran lebih berat dibandingkan sampel I, oleh karena itu kemampuan daya apung pada sampel II dan II lebih rendah dibandingkan sampel I. Menurut Amiruddin et al. (2014), yang menyatakan bahwa salah satu faktor yang mempengaruhi densitas atau kerapatan material Polyurethane adalah material Polyurethane yang dituang dalam kompartemen. Pengamatan dilakukan setiap 8 jam sekali selama 32 jam. Pada setiap jamnya terus mengalami penurunan nilai kemampuan daya apungnya dan pada jam ke-24 dan jam ke-32 didapatkan hasil yang konstan pada semua sampelnya. Menurut Dellino (1997), busa Polyurethane adalah rangkaian silang polymer yang cukup padat dengan susunan sel tertutup berupa gelembung dalam material, dengan dinding tidak terputus. Sehingga ada gas terkurung didalamnya. Hasil uji apung yang baik terdapat pada sampel I, karena pada sampel tersebut kemampuan dalam menahan bebannya paling tinggi. Hal tersebut dikarenakan nilai densitasnya yang rendah, maka berat foam polyurethane menjadi lebih ringan. Oleh karena itu, kemampuan apung pada sampel I paling tinggi. Uji apung dilakukan $3 x$ pengulangan, dikarenakan supaya data hasil yang didapatkan valid. Hasil dari perhitungan akhir dari uji apung, didapatkan hasil rata-rata dari volume foam polyurethane yaitu sebesar $324 \mathrm{~cm}^{3}$ dengan berat foam polyurethane sebesar 15 gram. Jadi, dengan berat foam polyurethane sebesar 15 gram dapat menahan beban fiber sebesar $1 \mathrm{~kg}$.

\section{Analisis Densitas/ kerapatan Foam Polyurethane}

Pengujian densitas/ kerapatan Foam Polyurethane dilakukan dengan menghitung massa dan volume dari masingmasing spesimen/ sampel. Densitas suatu sampel foam polyurethane dari lapangan dapat diketahui setelah di uji berat dan volumenya. Setelah dilakukannya uji apung pada Foam Polyurethane, maka selanjutnya akan dilakukannya perhitungan densitas dari masing-masing spesimen. Densitas/ kerapatan akan berpengaruh pada hasil uji apung. Semakin rendah densitasnya, maka semakin ringan berat pada foam polyurethanenya dan kemampuan daya apungnya akan semakin tinggi. Menurut Kirana et al. (2016), yang menyatakan bahwa pengujian densitas dilakukan dengan cara menghitung massa dan volume dari masing-masing spesimen untuk diketahui massa jenisnya. Berdasarkan hasil perhitungan, didapatkan hasil densitas Foam Polyurethane tersaji pada Tabel 5.

Tabel 5. Densitas Foam Polyurethane

\begin{tabular}{ccccc}
\hline No. & Sampel & $\begin{array}{c}\text { Volume } \\
\text { foam } \\
\text { polyurethane } \\
\left(\mathrm{cm}^{3}\right)\end{array}$ & $\begin{array}{c}\text { Berat } \\
(\mathrm{gr})\end{array}$ & $\begin{array}{c}\text { Densitas } \\
\left(\mathrm{kg} / \mathrm{m}^{3}\right)\end{array}$ \\
\hline 1. & I & 500 & 25 & 50 \\
2. & II & 500 & 27 & 54 \\
3. & III & 500 & 28 & 56 \\
\hline
\end{tabular}

Sumber: Penelitian, 2017.

(C) Copyright by Saintek Perikanan (Indonesian Journal of Fisheries Science and Technology), ISSN : 1858-4748 


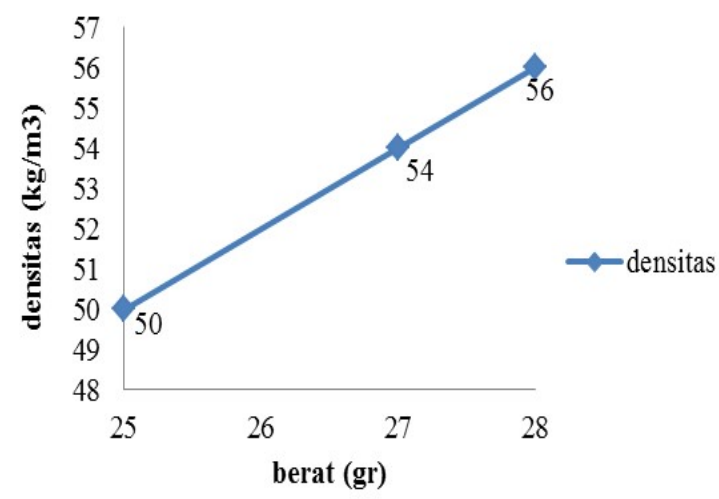

Gambar 3. Grafik hubungan nilai densitas dengan berat Foam Polyurethane

Berdasarkan gambar 3 diatas, didapatkan hasil densitas yang berbeda-beda tiap sampelnya. Sampel dengan densitas terendah terdapat pada sampel I yaitu sebesar 50 $\mathrm{kg} / \mathrm{m}^{3}$ dan sampel yang memiliki nilai densitas tertinggi terdapat pada sampel III yaitu sebesar $56 \mathrm{~kg} / \mathrm{m}^{3}$. Hal tersebut menunjukkan bahwa semakin berat pada sampel foam polyurethane, maka nilai densitasnya semakin tinggi. Oleh karena itu, maka nilai densitas berbanding lurus dengan nilai berat. Menurut Setiyanto dan Hartoko (2006), Bahan polyurethane dapat direncanakan menjadi lebih ringan lagi, dengan cara mengatur volume pengecoran. Pengurangan jumlah atau berat larutan yang dituang pada cetakan dengan volume yang sama menyebabkan densitas bahan semakin kecil, sehingga bahan menjadi lebih ringan. Densitas/ kerapatan akan mempengaruhi hasil uji apung pada foam polyurethane. Jika densitasnya rendah, maka kemampuan apung pada foam polyurethane menjadi tinggi. Hal tersebut dikarenakan sampel foam polyurethane yang semakin ringan beratnya. Jika sampel foam polyurethane semakin berat, maka kemampuan apungnya menjadi lebih rendah. Menurut Ilyas (1988), menyatakan bahwa untuk densitas material Polyurethane yang baik yaitu dibutuhkan sebesar $40 \mathrm{~kg} / \mathrm{m}^{3}$. Salah satu faktor yang mempengaruhi insulasi Polyurethane adalah densitas/ kerapatan material Polyurethane yang dituang dalam kompartemen.

\section{Analisis Kebutuhan Jumlah Foam}

\section{Polyurethane utuk mengapungkan kapal}

Hasil setelah dilakukannya analisis kemampuan daya apung pada Foam Polyurethane, langkah selanjutnya yaitu dilakukannya perhitungan keperluan Foam Polyurethane yang dibutuhkan untuk mengapungkan kapal. Perhitungan tersebut dilakukan dengan cara perkalian silang antara hasil uji apung dalam spesimen kecil dengan berat kapal yang sebenarnya yaitu 3 ton. Kebutuhan Foam Polyurethane tersebut bertujuan supaya bila terjadi kebocoran kapal dilaut, kapal akan tetap terapung karena adanya Foam tersebut. Sehingga perlu dilakukannya perhitungan yang tepat agar keselamatan saat dilaut tetap terjaga. Hasil uji apung menghasilkan bahwa 15 gram Foam Polyurethane dapat menahan beban fiber seberat 1 kg. Jika berat kapal yang sebenarnya adalah 3 ton, maka seberapa banyakkah Foam Polyurethane yang dibutuhkan. Berikut merupakan perhitungan kebutuhan Foam Polyurethane untuk mengapungkan kapal:

$$
\begin{aligned}
& \text { Diketahui }: \text { Foam Polyurethane }(\text { FPU })=15 \text { gr } \\
& =0,015 \mathrm{~kg} \\
& \text { Fiber (FRP) } \\
& =1 \mathrm{~kg} \\
& \text { Berat kapal } 5 \text { GT } \\
& =3 \text { ton } \\
& =3000 \mathrm{~kg} \\
& x=\frac{0,015 \times 3000}{1} \\
& =45 \mathrm{~kg}
\end{aligned}
$$

Hasil perhitungan diatas didapatkan hasil $45 \mathrm{~kg}$. Pada hasil uji apung menunjukkan 15 gram Polyurethane dapat menahan beban fiber sebesar $1 \mathrm{~kg}$ dan dengan nilai densitas sebesar $46 \mathrm{~kg} / \mathrm{m}^{3}$ berdasarkan lampiran 3. Diketahui berat kapal ikan fiber 5 GT sebesar 3 ton, maka untuk mengapungkan kapal dibutuhkan $45 \mathrm{~kg}$ Foam Polyurethane, maka dengan foam polyurethane sebesar $45 \mathrm{~kg}$ kondisi kapal bila mengalami kebocoran di laut kondisi kapal akan tetap terapung sama dengan permukaan air. Jadi, dalam pembuatan kapal ikan fiber 5 GT dengan berat 3 ton, dibutuhan Foam Polyurethane untuk satu kapal minimum sebesar $45 \mathrm{~kg}$.

\section{Analisis Kebutuhan Harga Polyurethane untuk mengapungkan kapal}

Foam Polyurethane yang dipasang pada bagian lambung kapal dan sebagai insulasi pada palka ikan tersebut. Foam Polyurethane ini juga berfungsi sebagai memperkuat konstruksi pada kapal ikan berbahan Fiberglass ini, sekaligus sebagai daya apung cadangan kapal guna untuk keselamatan bila terjadi kebocoran dilaut. Oleh karena itu setelah dilakukannya perhitungan dan analisa kebutuhan foam polyurethane yang diperlukan untuk mengapungkan kapal, dapat dihitung pula kebutuhan harga yang dibutuhkan untuk pemakaian polyurethane pada satu kapal. Berikut merupakan tabel harga Polyurethane yang diperlukan:

Tabel 6. Harga Polyurethane

\begin{tabular}{ccccc}
\hline No. & Bahan & $\begin{array}{c}\text { Berat } \\
(\mathrm{kg})\end{array}$ & $\begin{array}{c}\text { Harga } \\
(\mathrm{Rp})\end{array}$ & $\begin{array}{c}\text { Harga } \\
\text { per kilo } \\
(\mathrm{Rp})\end{array}$ \\
\hline 1. & $\begin{array}{l}\text { Polyuret- } \\
\text { hane A }\end{array}$ & 225 & 12.375 .000 & 55.000 \\
2. & $\begin{array}{l}\text { Polyuret- } \\
\text { hane B }\end{array}$ & 250 & 13.750 .000 & 55.000 \\
\hline & Total & 475 & 26.125 .000 & 110.000 \\
\hline
\end{tabular}

Sumber: PT. Jelajah Samudera Internasional Kab. Jepara.

Tabel 7. Kebutuhan Polyurethane untuk mengapungkan kapal

\begin{tabular}{cccc}
\hline \multirow{2}{*}{ No. } & \multirow{2}{*}{ Bahan } & \multicolumn{2}{c}{ Penggunaan Minimum } \\
\cline { 3 - 4 } & & Berat $(\mathrm{kg})$ & Harga $(\mathrm{Rp})$ \\
\hline 1. & Polyurethane A & 15 & 825.000 \\
2. & Polyurethane B & 30 & 1.650 .000 \\
\hline & Total & 45 & 2.475 .000 \\
\hline
\end{tabular}

Sumber: Penelitian, 2017. 
Berdasarkan tabel 6, harga Polyurethane per kilo pada galangan yaitu sebesar Rp 55.000 untuk polyurethane A dan Rp 55.000 untuk polyurethane B. Pemakaian dalam pengecoran polyurethane yaitu dengan perbandingan polyurethane $\mathrm{A}$ : polyurethane $\mathrm{B}$ sebesar 1 : 2 . Berdasarkan hasil uji apung pada kebutuhan harga pada tabel 7, dihasilkan bahwa kebutuhan polyurethane untuk satu kapal dibutuhkan sebanyak $45 \mathrm{~kg}$. Jadi dengan kebutuhan tersebut dapat diketahui pada polyurethane A sebanyak $15 \mathrm{~kg}$ dan polyurethane B sebanyak $30 \mathrm{~kg}$. Harga untuk kebutuhan polyurethane minimum yaitu sebesar Rp 2.475.000.

\section{KESIMPULAN}

kesimpulan yang dapat diambil pada penelitian Analisis Penggunaan Foam Polyurethane pada Kapal Ikan Fiber 5 GT sebagai Daya Apung Cadangan adalah : Hasil uji daya apung pada Foam Polyurethane yaitu terbukti bahwa Foam Polyurethane dapat menahan beban fiber. Berdasarkan uji apung diketahui bahwa 15 gr foam polyurethane dapat menahan beban fiber sebesar $1 \mathrm{~kg}$; Hasil perhitungan kebutuhan jumlah dan harga foam polyurethane yang diperlukan untuk mengapungkan kapal ukuran 5 GT yaitu diketahui kebutuhan minimum foam polyurethane yakni sebesar $45 \mathrm{~kg}$. Pada kebutuhan $45 \mathrm{~kg}$ foam polyurethane, jika kapal mengalami kebocoran dilaut maka kondisi kapal akan tetap terapung sama dengan permukaan air. Kebutuhan harga foam polyurethane yang diperlukan untuk satu kapal yakni diketahui sebesar Rp 2.475.000.

\section{DAFTAR PUSTAKA}

Amiruddin, W., Iskandar, B.H., Murdiyanto,B dan Baskoro,M.S. 2014. "Efisiensi Perubahan Kerapatan Material Laju Penetrasi Panas pada Palka Ikan Tradisional. [Disertasi].” Fakultas Teknik Perkapalan. Universitas Diponegoro.

Dellino, C.V.J. 1997. Cold and Chilled Storage Technology. Blackie Academic dan Professional. London.
Farhum, st. Aisyah. 2010. Kajian Stabilitas Kasko Kapal Pole and Line. Jurnal Ilmu Teknologi Kelautan Tropis 2(2): 53-61.

Ilyas, Sofyan. 1998. Teknologi Refrigerasi Hasil Perikanan Jilid I. Teknik Pendinginan Ikan. Jakarta.

Kirana,A., Farid,M dan Pratiwi, V.M. 2016. Efek Penambahan Serat Gelas pada Komposit Polyurethane terhadap Sifat Mekanik dan Sifat Fisik Komposit Doorpanel. Institut Teknik Sepuluh Nopember. Jurnal Teknik ITS. 5 (2): $38-41$.

Nurhasanah. 2016. Evaluasi Perbandingan Draft Kapal Ikan Fiberglass dan Kayu Berdasarkan Skenario Loadcase, Studi Kasus Kapal Ikan 3 GT. Politeknik Negeri Bengkalis. Jurnal Teknik Perkapalan. 13(2): 55-60.

Setiyanto, Indradi dan Hartoko, Agus. 2006. Uji Daya Apung Bahan Polyurethane dan Styrofoam. Jurnal Saintek Perikanan. 2 (1): 54-58.

Subandi. 2011. Deskripsi Kualitatif Sebagai Satu Metode dalam Penelitian Pertunjukan. Institut Seni Indonesia. Surakarta.

Suryana, S.A., Raharjo, I.P dan Sukandar. 2013. Pengaruh Panjang Jaring, Ukuran Kapal, PK mesin dan jumlah ABK Terhadap Produksi Ikan pada Alat Tangkap Purse Seine di Perairan Prigi Kabupaten Trenggalek- Jawa Timur. Univrsitas Brawijaya. PSPK Student Journal. 1(1): 36-49.

Torryselly, P.A. 2008. Analisa Efek Secondary Flow pada Pipa Bulat dan Kotak. [Skripsi]. Teknik Mesin. Universitas Indonesia.

Zenmansky, W.M dan Ditman, H.R. 1986. 1986. Kalor dan Termodinamika. ITB. Bandung. 